\title{
BARGAIN DIPLOMACY IN THE SYRIAN CRISIS
}

\author{
Saad Abudayeh \\ Faculty of International Studies - Political Science \\ Jordan University in Amman
}

\begin{abstract}
The Syrian crisis is different from other crisis in the region. There are two basic international players USA and Russia. AS well there are two basic regional players. From the beginning every one observed the huge media that the collapse of the regime is a matter of time. There was money, Arms, insurgents, media, and information which were used against Syria. But Syria survived. The pro Syria basic player Russia depended on several methods. Russia was clever in the diplomacy of bargains to save Syria mainly in the last summer and autumn, 2016.
\end{abstract}

Key words: diplomacy, zero sum game, Syria, Nusra Organization (Front).

\section{WHY THE SYRIAN CRISIS IS DIFFERENT}

Russia has been a basic player in the Syrian crisis since it started in 2011. Its main goals are to protect its interests by supporting the Syrian regime. It mobilized its efforts politically at the UN and mobilized the efforts of China to assist it in the coming battle. It worked with China from the beginning. On the regional level Iran has same goal as Russia. For Iran, the future of Hezbollah in Lebanon depends on the fate of Syria. For Iran and Russia, the conflict in Syria is a zero sum game. This is the main reason that makes the Syrian crisis different from the other crises in the area. The other side in the Syrian conflict does not have the same level of motivation. For opponents of the Syrian government, the conflict is not zero-sum game. Russia and Iran are involved in the Syrian conflict directly. American military operations depend on regional allies. Turkey, the GCC states, and the USA divided their efforts. For example, some in the GCC supported the Syrian opposition with money. Others send arms. Turkey paved the way for the insurgents. The door of Turkey was open for the insurgents from around the world. The borders were open for those who wanted to leave Syria. Some insurgents got involved in stealing oil, antiquities, and Syrian factories. 
Syria has avoided the fate of Libya, because it has very strong bilateral relations with international powers such as Russia and a regional power like Iran. It was able to survive and avoid the fate of Libya or Iraq.

The shake-up which started in 2011 in Arab states such as Egypt, Tunisia, Libya and Yemen, extended to Syria but did not force a change in regime. Although the people in Syria fought and were supported with money, technology and arms, no positive change took place in Syria.

The superpowers' role is different in Syria than Libya. The goals of the two superpowers, America and Russia, are different in Syria than their goals in the other Arab states. There is a real confrontation between the two powers. Iran appeared and took part in the regional conflict after 1979. Few people observed the change in the area after 1979. The development happened like this: Israel occupied Lebanon twice, in 1978 and 1982. The Arab world was weak. Egypt had already left the conflict. Iraq was busy with Iran in a war.

Iran interfered in the conflict in Lebanon in an unexpected way. It mobilized the Shiites in Lebanon and founded a new resistance in South Lebanon. Hezbollah was founded and became part of the conflict and resistance. A new problem appeared for the USA and Israel. Syria, the ally of Egypt before 1973 found new ally - Iran, e.g., it supported Iran in Lebanon. Since then Iran built strong bilateral relations with Syria. This is one of the main reasons causing Iran to get involved in protecting Syria and this became one of the main goals of Iranian foreign policy. This makes the situation in Syria different from Libya and Egypt or Yemen. Everything is different. When the struggle started in Syria in 2011, this author expected that the allies of the Syrian government would be more committed than the supporters of the Syrian protesters. The battle for regime change in Syria was full of expectations by Syria's enemies that they would defeat the regime in a few weeks. Half of the insurgents in Syria are from the al-Nusra organization (front). This is a terrorist organization changed that its name to Fateh al Sham (which means the Conquest of El Sham) (al Sham is the former name of Greater Syria). At the same time, the leader of this organization appeared in public. He is Abu Mohammad El Golani, who stated that he defected from the al-Qaeda Organization. More than fifty of the organization's cadres are Syrians.

\section{THE QUANTITY OF THE SUPPORTERS}

There is important factor that we must take into consideration. It is the quantity of the states that are fighting and supporting Syria. They are different from those who are supporting the insurgents. Another thing is the quality of the pro-Syrian block. Iran, Russia and Hezbollah have a cause, i.e., to defend Syria. For them it is a zero-sum game. On the other side there is no cause or the cause is not convincing. The people of Syria were scared by developments in the region. The Arabs in general do not believe that the goal of their struggle is 
to change the Syrian President Bashar al-Assad for the sake of democracy. No one believes that changing Assad is a greater priority than the situation in the West Bank and Gaza. The priority of the layman in the Arab World is to deter Israel there. Every Arab citizen is afraid that a change in Syria will lead Syria to the same fate as Iraq and Libya. The legitimacy of the Syrian president will be increased and he may become distinguished in the Arab world if he survives to the end. Needless to say, he did not build this fame; it was his allies' efforts and role. In any event, because the basic players are superpowers and the United States and its allies could not accomplish their goals, the fate of Syria has been decided by bargains.

\section{THE QUALITY OF THE OPPOSITION BLOCK IN SYRIA AND IRAQ}

There are several factors that helped the Syrian regime to survive for six years. The quality of the fighting level of the fighters supporting the regime is different from the quality of the Syrian insurgents fighting the regime. The role of Russia in assisting the Syrians is public. It sent its forces and established new bases. That happens in the high noon. Hezbollah, the ally of Iran, is fighting in Syria and Iran is publicly supporting the Syrian regime. But the US is fighting by proxy. It does not yet have the same level of allies in Syria, Iraq or Lebanon. It has regional allies like Turkey and some of the GCC states. Turkey became the supplier of the fighters to cross the borders and fight in Syria. It eased their entry into Turkey without a visa. The money comes from some of GCC states. But instead of backing her allies, USA accused her allies of terror. The US vice president Joe Biden, while visiting Turkey in October 2014, accused US allies--Turkey, Saudi Arabia, Qatar, and UAE--of supporting terror ${ }^{1}$. Although in public USA and its allies allied to fight Daesh (IS) in Syria. This alliance was accompanied by noise and media. Jordan, UAE and others joined. But after a Jordanian pilot was brutally killed by Daesh in November 2014, people have not heard publicly about Jordan's participation.

\section{AMERICA'S ALLIES ARE EXECUTIVES:}

The basic important players are Russia and USA. Each of them has allies in the region. The allies of the USA in Syria and Iraq cannot match the level of their rivals. USA did not work on this subject. While its opponents such as Iran were highly qualified in Iraq and Syria. I will quote one example when Daesh occupied half of Iraq in June 2014, The Grand Shiite leader Sheik Sistani declared al JE-

1 Russia Today (RT) channel broadcasted on 3 OCT 2014 the accusation and the protest of UEA. Biden changed some of his accusations. 
HAD al KEFAAEI, a fatwa, i.e., religious permission to resist and start fighting. $\mathrm{Ob}$ the other side, among the fighters of Daesh, you find things that were not known to the man in the street, e.g., that JEHAD EL NEKAH (permission to the fighters to possess women while fighting). It is to motivate the youth to join. It is not respected by the ordinary real Muslim. The allies of the USA used different methods to win. They used women to attract men to fight in Syria. USA closed its eyes about the massacres that were committed by the insurgents in Syria or Iraq. It closed its eyes about the insurgents and their supporters' behavior who stole the Syrian factories in Aleppo. The insurgents destroyed and stole ruins. They stole oil and sold it. The massacres scared others and destroyed the image of Islam. All these things affected the future of the insurgents in Syria and Iraq. Regardless of world public opinion, people consider them gangs and savages. They must behave in a proper manner to attract the people to join them against the regime. They accuse the regime of killing the people. They kill people in brutal ways and kidnapped nuns. They used the people as human shield. In Iraq, they kidnapped women and sold them. This behavior made people dislike them. They could have attracted the people to their cause, and they could have mobilized the people to fight the regime and force the president to step down. They accused the regime of using chemical weapons, but they were accused by UN reports of using them, too.

\section{SYRIANS DO NOT ACCEPT BEING RULED BY NON-SYRIANS}

I observed that all the historically accumulated experience was used by USA in Syria. Some of the extreme fundamentalists' fighters showed up in Syria. They are mainly from Saudi Arabia. This one of the mistakes. It is unknown to foreigners that these Saudi extremists are not well-liked among Syrians. The Syrians are advanced in their cultures. Syrians do not accept being ruled by non-Syrians or by people they consider inferior. This may be one of the factors which affected the unity of the Syrian insurgents. For example, the Nusra insurgents refused to join Daesh in one organization in Iraq when the leader of Daesh offered this.

\section{WHO IS BEHIND THE PROGRESS IN IRAQ AND SYRIA?}

Away from the methods of gangs used by the insurgents, Russia, which has the upper hand in Syria, administered the battles there. They are closer to international law. As well, they were patient to contain several powers. They succeed gradually. The Russians are the decision makers in Syria. They control all the parts. Iran will not resist Russia as long as its goals are the same as Russia's, i.e., to keep the regime in Syria safe. Iran is interested to keep the line to Hezbollah open to reach Hezbollah in Lebanon. Syria survived and avoided the fate of Libya. 


\section{GOOD RESULTS FOR SYRIA}

As a matter of fact, Syria improved its position when it cultivated the excellent results of war in Syria. It gets a better position and is protected by the Russians. The Israeli jet fighters will not fly in the skies of Syria and destroy military targets, despite accusing Syria of smuggling arms to Hezbollah in Lebanon. Now Hezbollah, which has been fighting in Syria for five years has stretched its forces into Syria to improve its strategy in facing Israel and its situation is now better than the past. Now that Russia is in Syria, it is not as easy for Israel to attack as it used to do. Turkey lost a lot of its presence in Syria. It is contained too. The losses for Israel are more than any other one.

\section{EXPECTED POSITIVE ENDS IN SYRIA}

The situation in Syria and Iraq is improving. There are some factors which lead to this development. First of all, the Russian intervention in Syria. That is the main reason for the expected positive ends in Syria. Other reasons for the development in Syria are the participation of Hezbollah and the Kurds. Both of them are highly qualified in fighting. There are other reasons, such as the Syrian government and people's style of facing these problems. Another reason is the absence of Turkey after the Russian intervention. So Syria was protected by Russia. That is the reason it avoided black days that were waiting for it; otherwise it would be in a worse position than Libya.

USA is engaged in all the fronts in the Middle East, but so far nothing affected the American position. By far there are no rulers in the Middle East who can lead the region. USA has no motivation to change its policy. It is worried more about Israel than about any other state in the region. It is worried about developments in Lebanon. It cannot bear the idea that there is a power in the region that affects or reduces the power of Israel. Israel was deterred by Hezbollah. That is one of the reasons the USA insists on reducing the power of Syria so as to reduce the power of Hezbollah.

So the Russian intervention deterred these two powerful states. Now neither Turkey nor Israel can provoke Syria. Even USA cannot do that. Two months ago USA complained that there was an attack by the Russian jet fighters against American-armed insurgents in the south of Syria. When John Kerry, the US secretary of state, raised his voice, the Russian defence minister flew to Syria inspecting the important Russian base in the north and sending the Americans a message. Earlier, Russia stated that the USA must have the permission of the Syrian Government if it wanted to enter Syria. The USA, France and UK ignored that, but they cannot ignore it for a long time 


\section{THE BARGAINS ERA}

I observed that Russia leads the bargain diplomacy in Syria. It demonstrated its muscles in Syria through military intervention, but it made several important bargains. BBC on 25 August 2016 mentioned the UN report about the use of chemical weapons by both sides in 2014 and $2015^{2}$. The report says this comes after the crisis of 2013 when USA accused Syria of using such weapons. At that time, Russia was the honest broker who interfered to finish the crisis by making Syria get rid of the weapon and with that, it stopped the US campaign to attack Syria. That was one of the great bargains. But the bargains continued after Turkey reconciled with Russia in June $2016^{3}$.

\section{THE FUTURE OF SYRIA IS DECIDED BY THE BARGAINS:}

The future of Syria is decided by the bargains now. In the last three months we may observe that there are bargains behind the scenes that are directing events in Syria. Recently the agreement between USA and Russia on 9 September 2012 reflects that the events are directed by the bargains of the prime players ${ }^{4}$. The bargains which took place on the $9^{\text {th }}$ of September reflect that there are two superpowers directing the events in Syria. It ends with bargains that are surrounded in secrecy. Journalists got nothing when they met the foreign ministers of Russia and USA. It was supposed that Russia will put pressure on Syria and Iran at the same time. The name of Iran was not mentioned clearly. All the other parties had no principal role. A second secret bargain preceded the crossings by the Turks into Syrian territory, called the battle of Jarablus (city on the border of Turkey) in the north of Syria to remove Daesh insurgents from the city. That was not a battle. It is great noise with no real fighting. It is part of bargain. It permits Daesh to leave peacefully to Idlib or El Riqih. I expect another bargain in the near future. On August 25, 2016 there was another bargain in the city of Daria, near Damascus. There, 700 insurgents left Daria peacefully without heavy machines and guns. There were 4000 civilians who were deported to a safe place. So there are several bargains in a short period. On $10^{\text {th }}$ September 2016 the BBC talks about another bargain on the movement of insurgents to safe places. The name was not identified at the time ${ }^{5}$. But it was a bargain, not war. In the north when Turkey crossed the borders, it declared that it was the beginning of battles against Daesh and others to shield the Euphrates. As a matter of fact, there was no battle. According to eye witnesses, there were no fires, Daesh left peacefully. The Turks and their support-

2 BBC covered the occasion in details.

3 Russia Today (RT) channel covered the reconciliation on 20 June 2016.

4 BBC covered this issue in professional way.

5 BBC interviews by Syrian Official. 
ers advanced to defeat the Kurdish forces. The Kurds were supposed to move to the east of Euphrates. I expect there is a bargain, too, that the USA, Turkey, Russia played this game to save the lives of the insurgents. This happened in Jarablus and Daria, too. In one day and in few seconds the battle of Jarablus was finished. As a matter of fact it has not started at all. In the same day it was declared that the Kurds left to the east, following American advice to stay east of the Euphrates. In the same day the insurgents left Daria ${ }^{6}$.

So bargains are the methods for more positive results in Syria. This increased after the reconciliation between Russia and Turkey and after the failed coup in Turkey. Turkey changed its attitude and reconciled with Russia and Iran. Here is a bargain too. It changed its demands and is no longer talking about the removal of Assad. It accepts the Russian and Iranian ideas about this subject. The Turkish leader visited Russia and Iran. So he is in the other camp. At the end it may be noted that bargains have achieved more than wars and the most important things were done by bargains and telephone calls not Jetfighters or tanks.

\section{BIBLIOGRAPHY}

1. BBC (British Broad Cast)

2. Russia Today (RT) channel covered the reconciliation on 20 June 2016

3. Personal diaries.

Dr. Saad Abudayeh is professor of Political Science in the Faculty of International Studies - Political Science at Jordan University in Amman and the chairman of the Chair of the Pakistani Studies in the university. He is an ex-diplomat and author of forty one books about the area. He was decorated by King Abdullah II for his cultural activities. He was awarded the distinguished research prize by Jordan University. His e-mail is abudayeh@hotmail.com

${ }^{6}$ City near Damascus, President Assad prayed in it in the Eid Al Adha on 12 SEPT 2016. 